\title{
OPEN
}

\section{Publisher Correction: Cretaceous amber fossils highlight the evolutionary history and morphological conservatism of land snails}

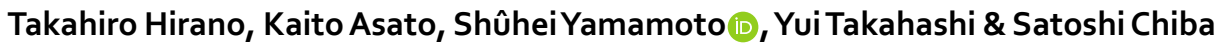 \\ Correction to: Scientific Reports https://doi.org/10.1038/s41598-019-51840-3, published online 04 November \\ 2019
}

The publication date was omitted from the original PDF version of this Article. This error has now been corrected in the PDF version; the HTML version was correct from the time of publication.

Additionally, the URL in the section entitled "Data Availability" did not link to the correct figshare database. This has been corrected in both the HTML and PDF versions.

(c) Open Access This article is licensed under a Creative Commons Attribution 4.0 International License, which permits use, sharing, adaptation, distribution and reproduction in any medium or format, as long as you give appropriate credit to the original author(s) and the source, provide a link to the Creative Commons license, and indicate if changes were made. The images or other third party material in this article are included in the article's Creative Commons license, unless indicated otherwise in a credit line to the material. If material is not included in the article's Creative Commons license and your intended use is not permitted by statutory regulation or exceeds the permitted use, you will need to obtain permission directly from the copyright holder. To view a copy of this license, visit http://creativecommons.org/licenses/by/4.0/.

(C) The Author(s) 2019 